\title{
CLINICAL STUDIES OF THE BLOOD VOLUME. VIII. MACROCYTIC AND HYPOCHROMIC ANEMIAS DUE TO CHRONIC BLOOD LOSS, HEMOLYSIS AND MISCELLANEOUS CAUSES, AND POLYCYTHEMIA VERA ${ }^{1}$
}

\author{
By JOHN G. GIBSON, 2D, ALFRED W. HARRIS, AND VERNE W. SWIGERT \\ (From the Medical Clinic of the Peter Bent Brigham Hospital and the Department of Medicine, \\ Harvard Medical School; and the Robert Dawson Evans Memorial for \\ Clinical Research and Preventive Medicine, Boston)
}

(Received for publication July 13, 1939)

Early studies of the blood volume in secondary anemia leave considerable doubt concerning the actual state of the blood volume and the relation thereof to the severity of the anemia. Keith, Rowntree and Geraghty (1) concluded from the results obtained with the original dye method that " considerable variation exists in the total blood volume and plasma volume in cases of secondary anemia." Subsequent limited studies utilizing modifications of both the carbon monoxide and the dye method have found plasma increased $(1,2$, 3 and 4), normal, or not increased (1, 5, 6 and $7)$. Total blood volume was considered as increased despite decreased red cell volume $(2,3$ and 4$)$, within normal limits (1) or decreased (3, $4,5,6$ and 7 ). In chlorosis total blood volume was found to be high ( 3 and 8 ), or decreased (2).

This confusing state of affairs arose probably as much from a failure to classify anemias etiologically as from the discrepancies in accepted normal standards of the widely varying and none too reliable techniques employed. None of the above authors could find any relationship between the abnormality of blood volume and the severity of the anemia. However, Robertson and Bock (9) found a markedly decreased total blood volume in soldiers after hemorrhage, frequently as low as 60 per cent of normal. They stated that after a certain point the reduction in volume seemed to parallel the decrease in blood pressure. At this stage they thought the blood volume was not restored by body fluids, since such replacement would but further dilute the blood and lower hemoglobin concentration. In this critical condition any increase in total blood volume was considered

\footnotetext{
1 This study was aided by a grant from the Proctor Fund for the Study of Chronic Diseases, Harvard Medical School.
}

to be due to an increase in red cells only. Bock (10) stated that in chronic anemia "the blood volume . . . is diminished in direct proportion to the decrease in corpuscles." Griesbach (3) stated that in "healed" cases of secondary anemia the blood volume was parallel to the state of healing. The most thorough study of the relationship of blood volume to anemia is that of Bennett, et al. (11) in 1938. In their opinion " the estimation of blood volume is a genuine criterion of the severity (of anemia) as indicated by the fact that the fatal cases comprised a group in whom the blood volume was notably reduced."

The subject of blood volume in polycythemia vera has received a great deal of attention, all workers agreeing that the total blood volume is tremendously increased $(2,10$ and 12 to 19 inclusive) due almost entirely to a great volume of circulating red cells, the plasma volume being either normal or slightly increased (10), or decreased (14 and 15). Haden (19) considered that the red cell count gave too low an index of the total increase in red cells, but thought that the red cell mass per kilogram of body weight was the most sensitive indicator of the changes in the red cells.

Since we have found a striking relationship between the severity of anemia and the level of plasma, circulating red cell and total blood volume in pernicious anemia (20) and in Bright's disease (21), it seemed worth while to make a similar study of secondary anemia. The main interest of such a study is to correlate the blood volume level with the clinical course, and in light of these findings to evaluate from a clinical standpoint the common laboratory criteria of anemia: the red cell count, hemoglobin and hematocrit. It also seemed of interest to make similar studies in cases of polycythemia vera for comparison with results found 
in anemia, since frequently the subjective symptoms of both conditions are very similar.

\section{MATERIAL STUDIED}

Thirty-two patients with anemia from the Medical and Surgical Wards of the Peter Bent Brigham Hospital and 9 from the Robert Dawson Evans Memorial, Boston, were studied. Of these, 8 males and 12 females had anemias due to blood loss; 2 males and 9 females had hypochromic anemias of unknown cause; 3 males and 3 females had so-called macrocytic anemias, and 2 males and 2 females had hemolytic anemias due to congenital hemolytic jaundice, malaria or sulfanilamide intoxication. In 7 males and 9 females repeated determinations were made during recovery. None of these cases were in an acute hemorrhagic stage, sufficient time having elapsed between the onset of hemorrhage and the determination of blood volume to permit physiological compensation by tissue fluid to take place. Adequate fluid administration was carried out in this interval. In this study we were not concerned with volume changes immediately after acute blood loss. No patient in the group studied succumbed to anemia and many whose course was not followed made complete recoveries on iron therapy, transfusion, or both.

Of the 11 cases of polycythemia vera studied, 5 males and 3 females were from the Medical Service of the Peter Bent Brigham Hospital and 1 male and 2 females from the Robert Dawson Evans Memorial. In 2 males and 1 female repeated determinations were made during the course of treatment.

\section{METHODS}

Plasma and total blood volumes and hematocrits were determined by methods previously described (22), venous pressures by a direct manometric method (23), circulation time by means of decholin (24), and hemoglobin content of venous blood by a modification of the method of Osgood and Haskins (25). Height was taken as the basis for the prediction of normal blood volume. Normal values for hematocrit were taken as 44 per cent and 40 per cent (26), for red blood cell counts as $5,480,000$ and $4,920,000$ cells per cu. mm. of blood, and for hemoglobin content of venous blood as 15.4 and 14.8 grams per $100 \mathrm{cc}$. of whole blood (27), for males and females respectively.
RESULTS

\section{Blood volume}

Absolute plasma, circulating red cell and total blood volume in the 16 cases of anemia followed during recovery are shown in Table $I$ in relation to the red cell count. Plasma volume was above the range of average normal value in all except 3 cases. In those cases with higher than normal volumes there was a general tendency for plasma to decrease as the red cell count rose. In 2 of the cases with subnormal values plasma volume increased during recovery. Circulating red cell volume was below normal in all cases and increased as the red cell count rose. There was a definite tendency towards a direct relationship between the degree of lowering of red cell volume and anemia.

At the time of the initial determination only 5 cases had a total blood volume above normal. During recovery total blood volume fluctuated but there was a general tendency for the total blood volume to increase in the cases in which subnormal values were found and to decrease in those in which higher than normal values were found at the initial determination, and with 3 exceptions total blood volume was within the range of normality at a level of from 4.5 to 5.5 million red cells.

Considered from the point of view of predicted normal blood volume for the individual, there was some discrepancy in plasma, circulating red cell and total blood volume in relation to the red cell count as illustrated in Figure 1. While the average trend of plasma volume was to be above normal at a low red cell count, decreasing during recovery, the spread of cases above and below normal was considerable. This characteristic was not peculiar to any one of the etiologic groups.

Circulating red cell volume was below the predicted normal red cell volume for males and females in all but 1 case (Case EM-9A with macrocytic anemia) at the time of the initial determination. The trend toward a direct relationship between the deficit in red cell volume and level of anemia, indicated by the average line in Figure 1, was much more definite than in the case of plasma volume.

Total blood volume was subnormal in all but 6 instances at the time of the initial observation and 


\begin{tabular}{|c|c|c|c|c|}
\hline \multirow{18}{*}{ 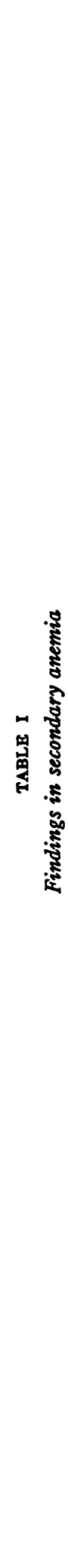 } & 离 & & \multirow{18}{*}{ 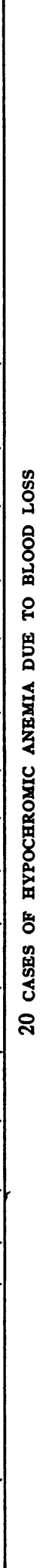 } & 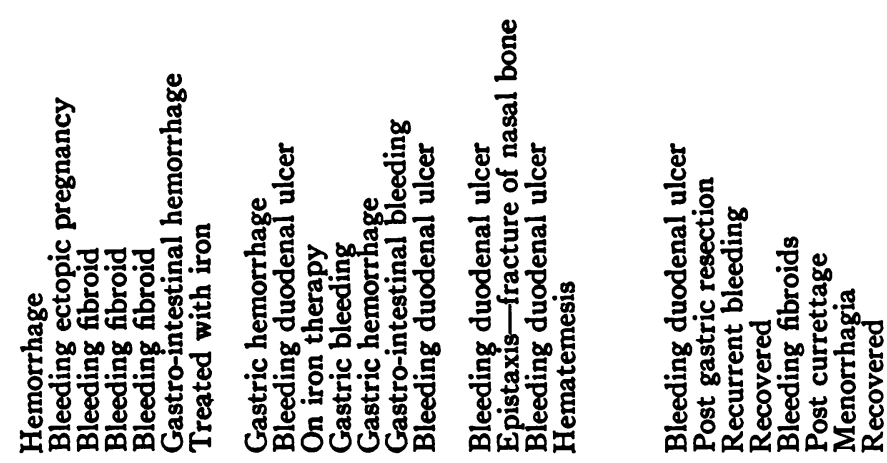 \\
\hline & 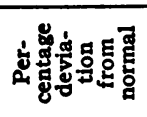 & 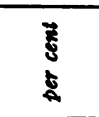 & & 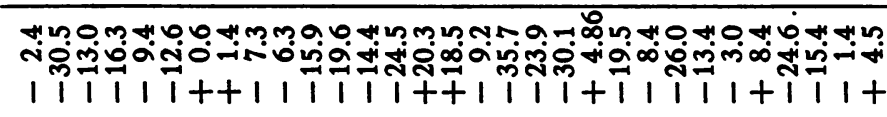 \\
\hline & 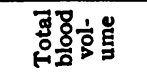 & $\dot{s}$ & & ผ \\
\hline & 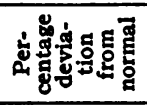 & $\begin{array}{l}3 \\
8 \\
8\end{array}$ & & 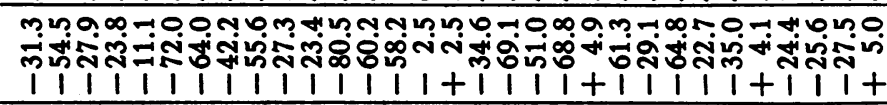 \\
\hline & 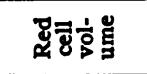 & s. & & 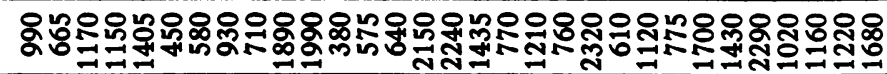 \\
\hline & 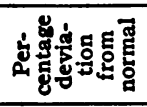 & $\begin{array}{c}8 \\
\vdots \\
\end{array}$ & &  \\
\hline & 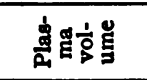 & ذ̇ & & 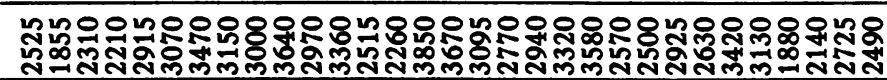 \\
\hline & 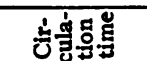 & 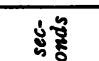 & & 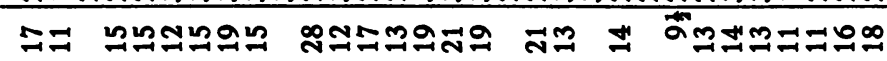 \\
\hline & 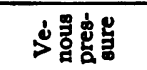 & 串 & & 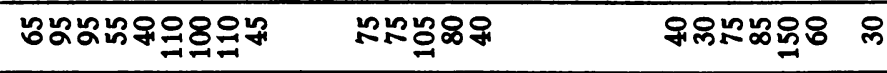 \\
\hline & 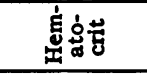 & 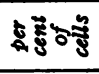 & & 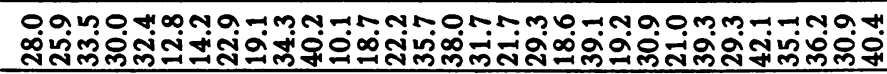 \\
\hline & 送 & है: & & 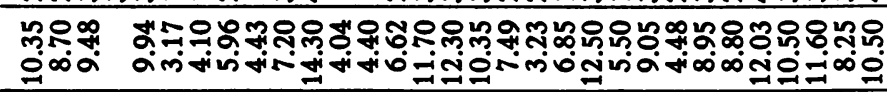 \\
\hline & 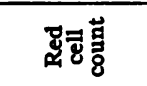 & 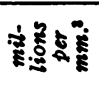 & & 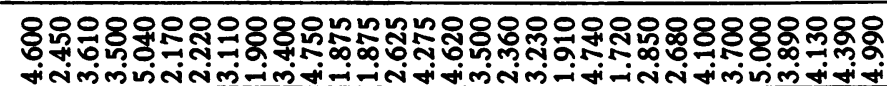 \\
\hline & 葋 & $\dot{E}$ & & 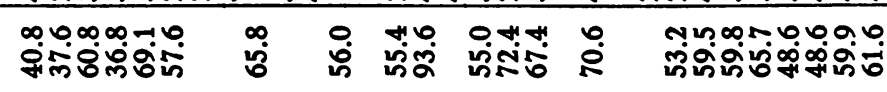 \\
\hline & 葶 & $\dot{8}$ & & 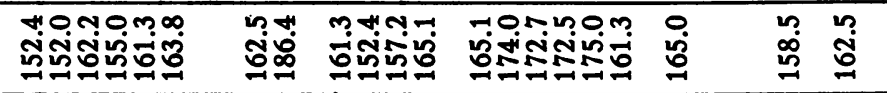 \\
\hline & $\ddot{z}$ & 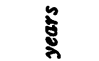 & & 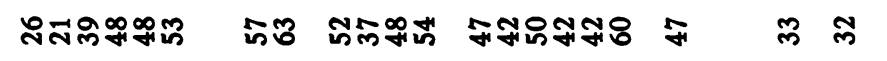 \\
\hline & 8 & & & 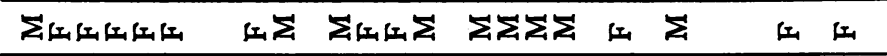 \\
\hline & مّ & & & 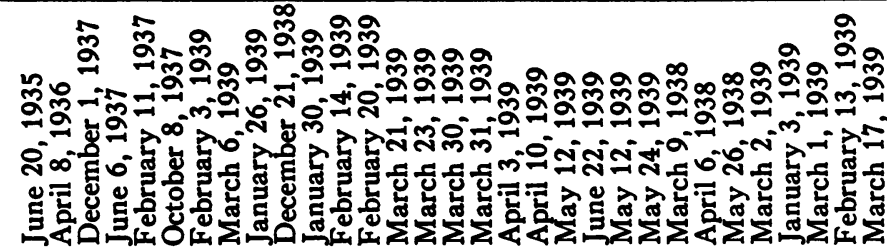 \\
\hline & ठ̊. & & &  \\
\hline
\end{tabular}




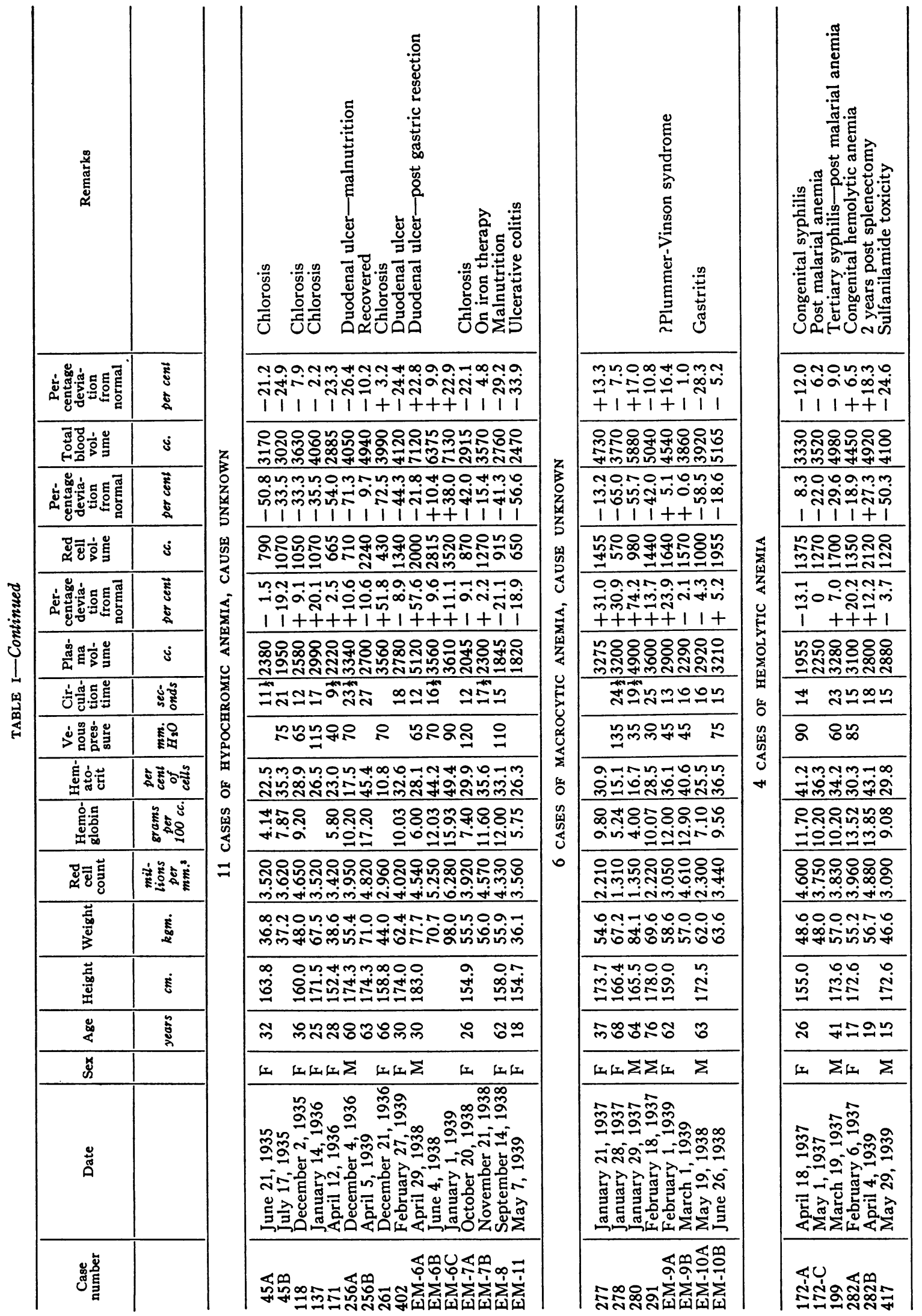




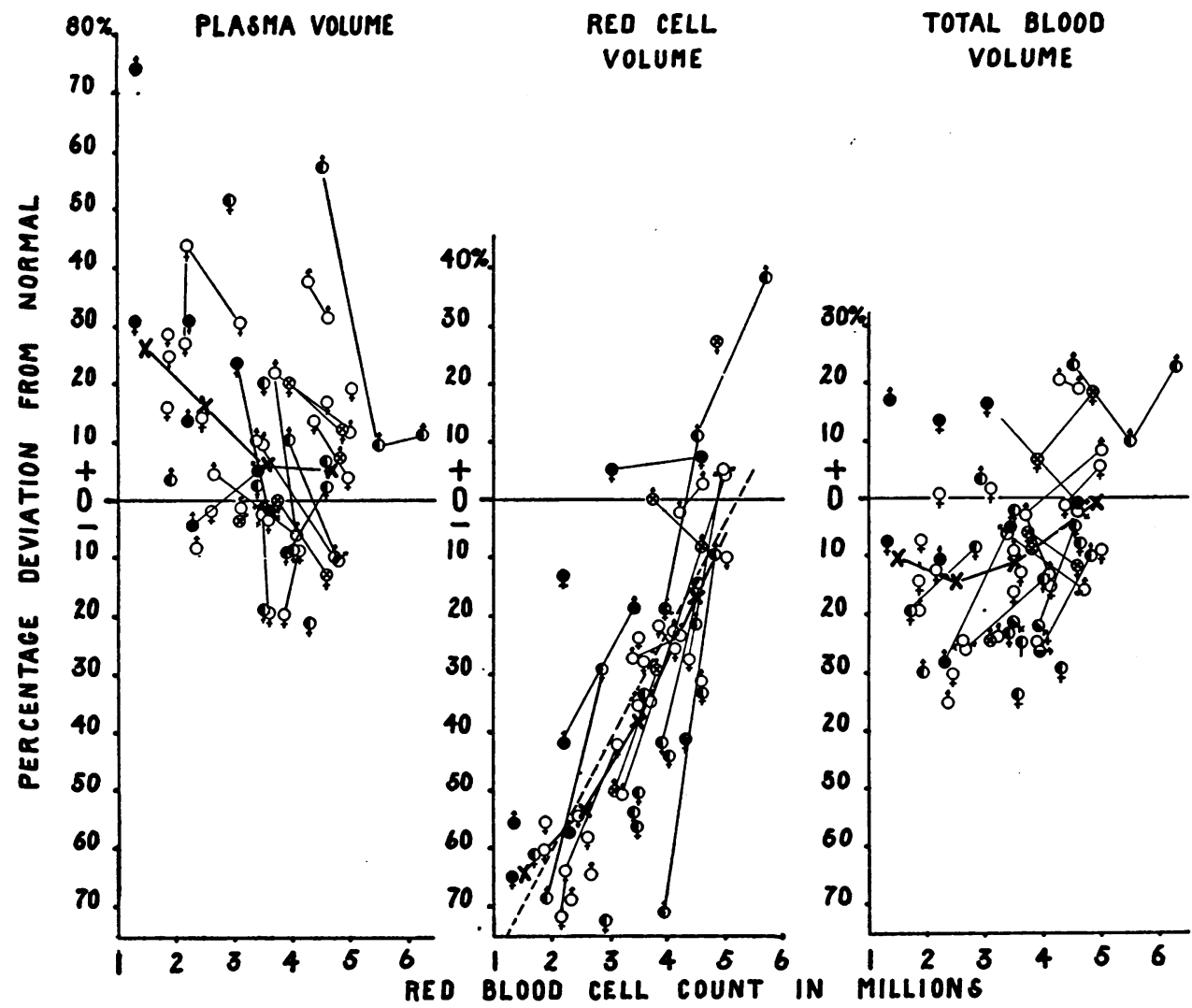

Fig. 1. Changes in Blood Volume in Secondary Anemia in Relation to Normal

Symbols refer to etiologic groups as follows: anemia due to blood loss $O$; hypochromic anemia, cause unknown $\bullet$; macrocytic anemia $\bullet$; and hemolytic anemia $\otimes$. While there are wide variations in volume, the average trend in secondary anemia, indicated by the heavy black lines, is for plasma volume to be above and total blood volume to be below normal in severe anemia, due to a greatly diminished red cell volume. As the red blood cell volume increases the relationship of changes in plasma and red cell volume is such that the increase in total red cell mass bears a direct relationship to the erythrocyte level.

the trend was to be low until the red cell count rose to approximately 4 million cells. However, the relationship between total blood volume and level of anemia was distinctly less evident than in the case of the circulating red cell volume.

The data obtained in the cases of polycythemia vera are summarized in Table II. In the untreated stage total blood volume was well above normal for the individual without exception as shown in Figure 2, and the increase was definitely in relation to the red cell count. Plasma volume was below normal in 7 and above normal in 4 cases when first observed, the average trend bearing no relationship to the red cell count. Circulating red cell volume was definitely increased in all cases, being greater than 150 per cent above normal in 6 of the 11 cases in the untreated stage. Case 383 with a red cell count of 14.065 million cells had a circulating red cell volume of 388 per cent above normal. The linear relationship between the degree of increase above normal in total circulating red cell volume and red cell count was equally as striking as in the cases of anemia.

Treatment consisted of repeated phlebotomies in 2 cases. No significant change in plasma volume resulted but large reductions in circulating red cell, and hence in total blood volume, were effected and these followed closely to the general trend in relation to red cell count. In Case EM14 the removal of a total of $8,000 \mathrm{cc}$. of blood by repeated phlebotomies during a period of about 11 weeks reduced the circulating red cell volume 


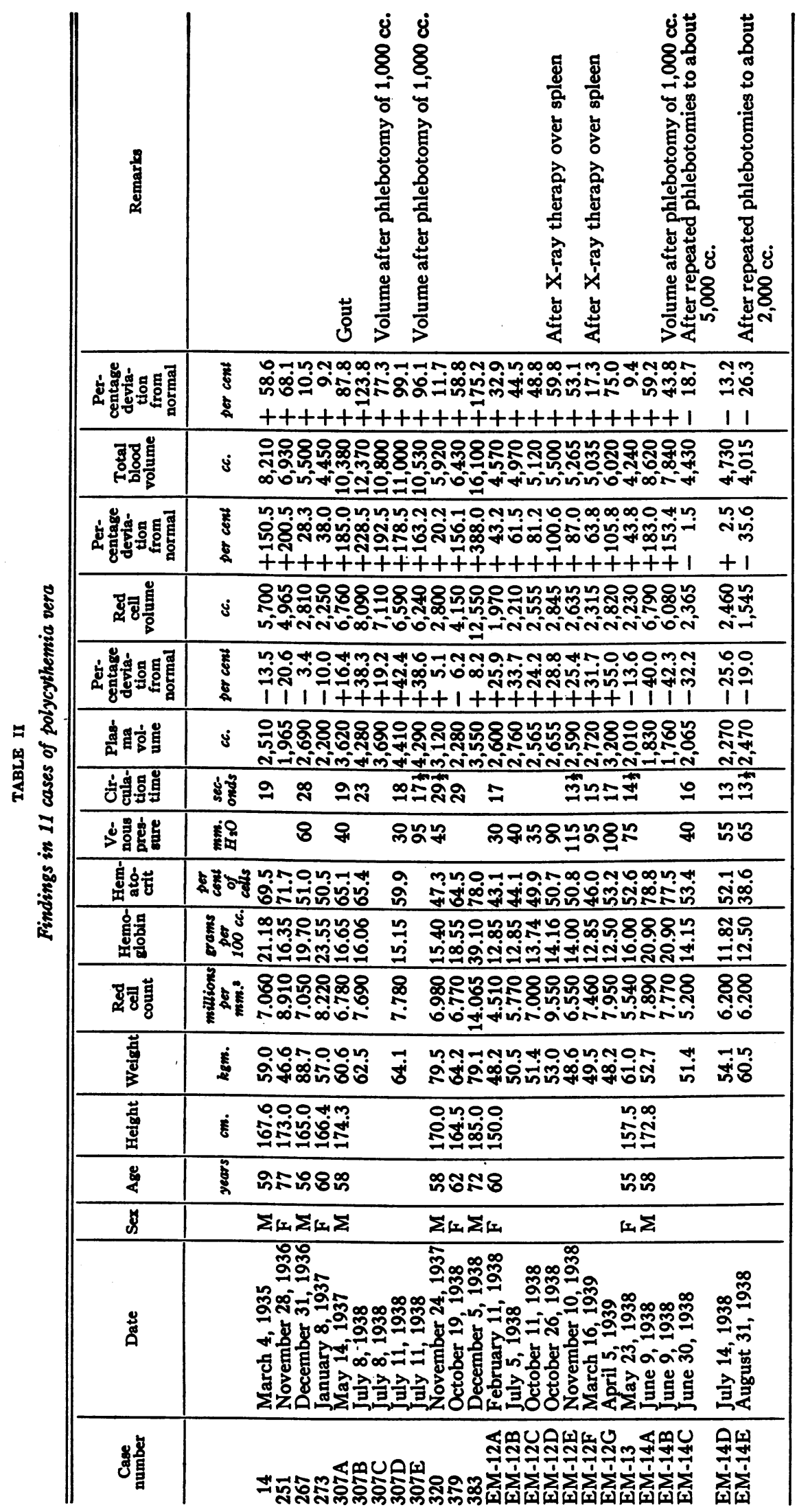




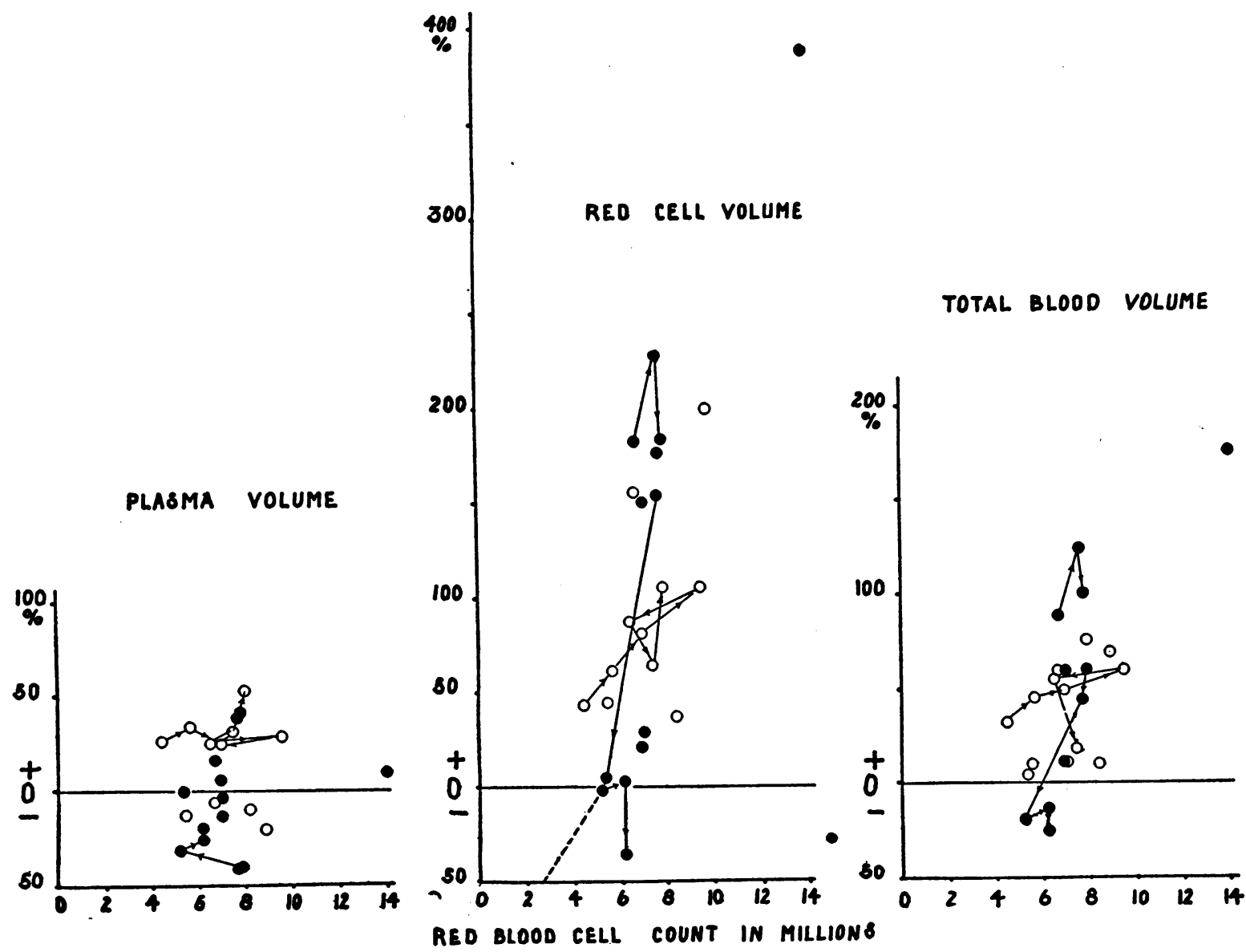

Fig. 2. Blood Volume in Polycythemia Vera

Black circles represent males and open circles females. Solid lines indicate the changes in individual cases. Tctal blood volume is greatly increased due to an increase in circulating red cell volume. The average trend of increase in red cell volume constitutes a continuation of the line representing a direct relationship between the level of total red cell mass and red blood cell count obtaining in secondary anemia.

from 183 per cent above to 35.6 per cent below normal, and total blood volume from 59.2 per cent above to 26.3 per cent below normal.

\section{Circulation time}

Circulation time tended to be fast in anemia and slow in polycythemia as indicated in Figure 3. In the former group in 9 instances the circulation time was slower than 20 seconds and in 20 faster than 15 seconds while, in the latter group of 16 observations, 4 were slower than 20 seconds and only 4 faster than 15 seconds. None of these patients showed any evidence of congestive heart failure or of metabolic disturbance. When both groups were considered as a whole there was a continuous slowing in circulation time accompanying an increase in erythrocyte level. In the group of anemias no one etiologic group exhibited any particular deviation from the general trend.

\section{Venous pressure}

In anemia, venous pressure varied between 30 and $150 \mathrm{~mm}$. of water, averaging about 50 , and in polycythemia vera between 30 and $115 \mathrm{~mm}$. of water, averaging about 40 . There was no relationship between the venous pressure and total blood volume during the severe stages or during periods of clinical improvement in either anemia or polycythemia vera.

\section{DISCUSSION}

From these results it seems reasonable to conclude that secondary anemia is characterized by a low total blood volume, due primarily to a great 


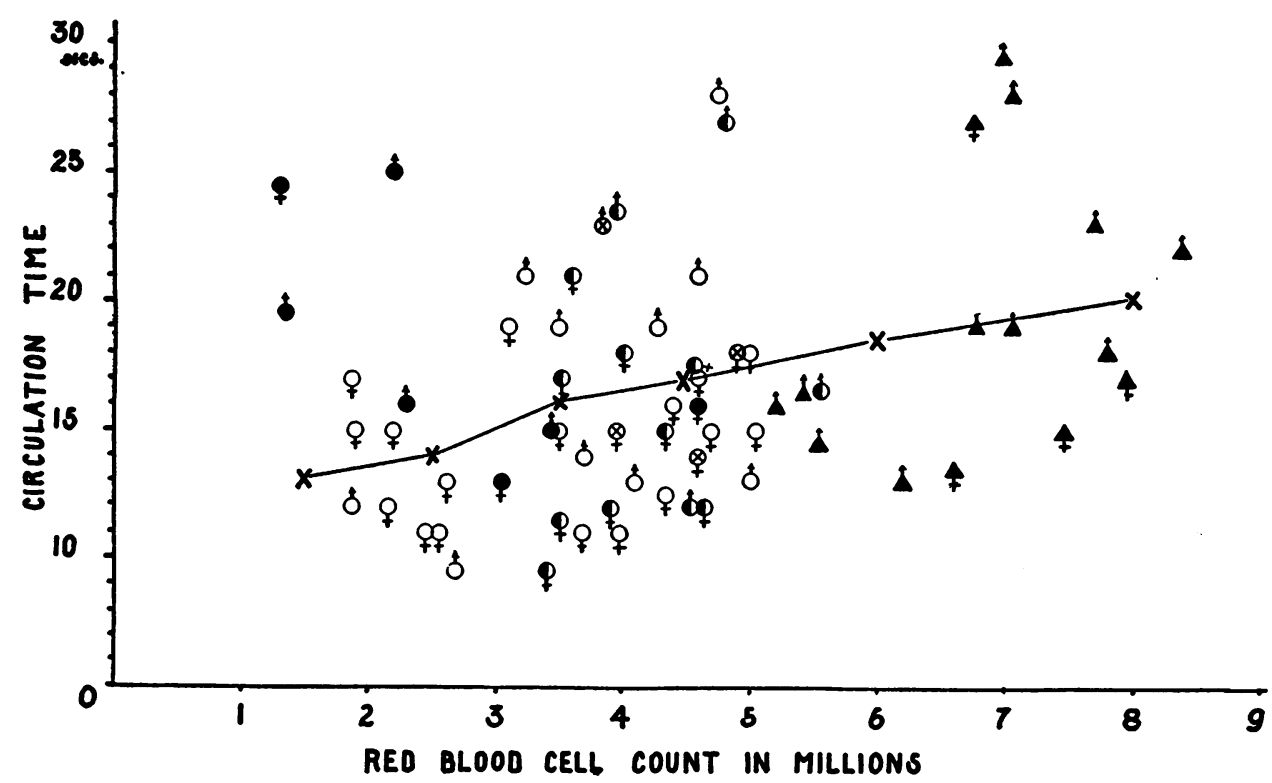

Fig. 3. Circulation Time in Secondary Anemia and Polycythemia Vera

Symbols refer to etiologic groups as follows: anemia due to blood loss $O$; hypochromic

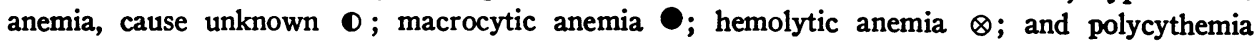
vera $\Delta$. Circulation time becomes progressively slower as the erythrocyte level increases.

reduction in the circulating red cell volume, despite an increased plasma volume. While in the individual case total blood volume may be within normal limits, the circulating red cell volume is below normal and the deficit in red cell mass is in direct relationship to the severity of the anemia as evidenced by the red cell count, hemoglobin determination or hematocrit level. During recovery there is an increase in circulating red cell volume and the relationship of changes in plasma and red cell volume is such that this increase tends to be directly proportional to changes in the red cell count, hemoglobin determination and hematocrit level.

This same relationship was observed in the cases of polycythemia vera. The theoretical slope of the direct relationship between the level of anemia and circulating red cell volume is shown in Figure 1 by the broken line. It is of some interest that the average of the deviation from predicted normal circulating red cell volume in the cases of polycythemia vera shown in Figure 2 constitutes a continuation of this line. Changes in circulating red cell volume effected by phlebotomy and occurring during relapses tended to follow this line closely.
This characteristic of the course of the circulating red cell volume in anemia offers a valid basis for the evaluation of the significance of the red cell count, hemoglobin determination and hematocrit as clinical guides to the severity of anemia in a given case. By reference to the curves for the theoretical direct relationship of circulating red cell volume to red cell count, hemoglobin or hematocrit shown in Figure 4, the theoretical deficit in red cell mass can be estimated. The agreement between this theoretical and the actually determined deficit in red cell mass should furnish a clue to the usefulness of the procedures in question. The best correlation obtains in the case of the hematocrit level in which in 61 observations 90 per cent of the cases fell within plus or minus 20 per cent and 69 per cent within plus or minus 15 per cent of the theoretical value. The correlation with the red cell count was less good and that with the hemoglobin determination was least good of the three procedures. For clinical purposes it would appear that the hematocrit gives a better index of the severity of anemia than does the red cell count or the hemoglobin determination.

With these facts in mind certain deductions can be made concerning the actual deficit in circulating 


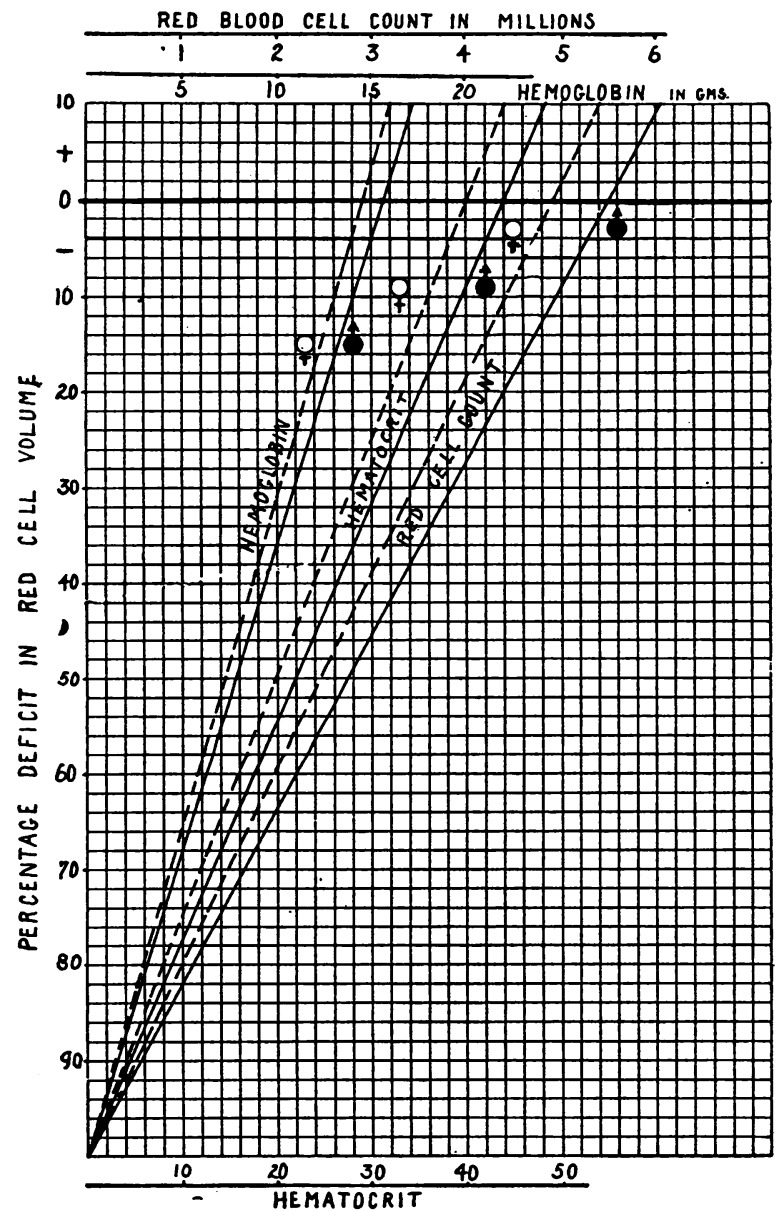

Fig. 4. Nomogram for Estimation of Deficit in Circulating Red Cell Volume in Secondary Anemia

red cell volume obtaining in a given case at any level of anemia. Furthermore, some idea can be gained of the amount of whole blood that need be administered to restore the circulating red cell volume to normal. Chronic anemias of the type studied sometimes require transfusion as a lifesaving procedure and no guide for estimating transfusion requirements is in common use. This requirement may be computed as follows: Normal circulating red cell volume may be derived from predicted normal total blood volume on the basis of either height or surface area, using the nomogram in a previous communication (26), and taking the hematocrit values as 44 and 40 for males and females respectively. The theoretical percentage of reduction from normal at any given level of red cell count, hemoglobin or hematocrit may then be derived from the curves in Figure 4, and the actual deficit in circulating red cell volume computed by multiplying the derived normal circulating red cell volume by this percentage. If the average hematocrit value of donor's blood be considered as 40 , the total amount of whole blood required to restore the patient's circulating red cell volume to any desired level may be computed.

It should be emphasized that, while this computation is valid within the above-stated limits for cases of chronic anemia, it may not be in cases of acute blood loss in the immediate post-hemorrhagic period or while hemorrhage is continuing. Bennett, et al. (11) followed the course of the blood volume by a dye method in 122 cases of severe gastro-intestinal bleeding and concluded that " assessments of the severity of anemia based on hemoglobin estimations are liable to grave error, particularly in the hours just following hemorrhage when dilution by plasma may, by lowering the hemoglobin concentration, give a false idea of the true level of total red cell volume." They also stated that the "determination of blood volume is a real criterion of the severity of anemia" and that "the red cell portion of the blood volume is the all important factor." We feel that the dye method used by these authors is open to criticism (22 and 28). It is quite possible that the lack of correlation between hemoglobin and red cell volume noted may have been due to technical aberrations. We agree with these authors concerning the importance of the blood volume determination in assessing the severity of anemia and with the concept that the deficit in red cell mass is the one important fact from the clinical point of view in evaluating the severity of anemia.

It is worthy of comment that, as regards the state and course of blood volume in anemia, with a few unimportant exceptions, all anemias are essentially similar as shown in Figure 5. Regardless of etiology the circulating red cell volume exhibits the same characteristics in all anemias.

Our findings in polycythemia vera are in keeping with those previously reported. It is impressive to realize the truly enormous quantity of blood contained within the vascular bed of these patients, many of whom were cachectic and emaciated.

Haden (19) found that the red cell count did not accurately measure the total increase in red cells since it was " relatively too low." As shown in Figure 2, the relationship of plasma, circulating 


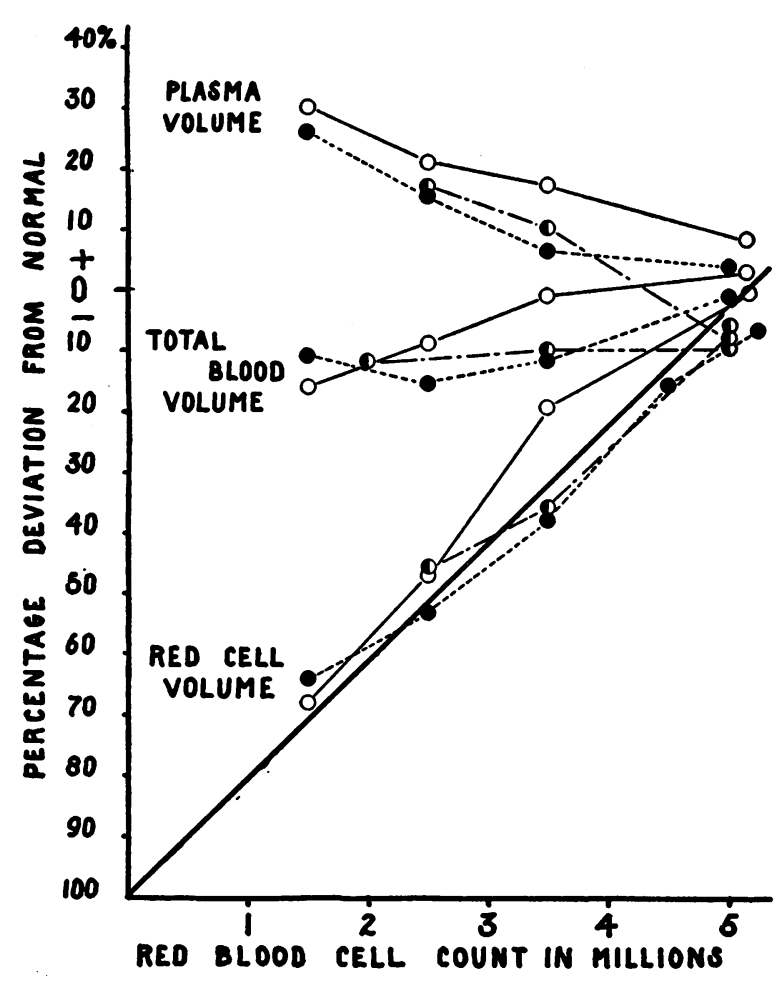

Fig. 5. Blood Volume Changes in Anemia

The symbols refer to the following classifications of anemia: pernicious anemia $O$; anemia due to Bright's disease $\mathrm{O}$; and secondary anemia, all causes $\bigcirc$. There is a striking similarity in the deviation from normal in plasma, circulating red cell and total blood volume and the changes during recovery in all groups.

red cell and total blood volume in terms of percentage of normal to the red cell count reveals that the red cell count is a very fair indicator of the degree of elevation above normal of both circulating red cell and total blood volume. In the phlebotomized cases the changes in circulating red cell and total blood volume followed the general trend very closely during the periods of falling volume after bleeding and the periods of increasing volume during relapse.

None of the cases of polycythemia vera studied had congestive heart failure, elevated venous pressure or circulation times slower than $\mathbf{3 0}$ seconds. In comparison with a group of cases with congestive heart failure (29) in whom increases in both plasma and circulating red cell volume brought about an increase in total blood volume which was on an average 40 per cent above normal-only 6 cases out of 35 being more than 60 per cent above normal - total blood volume in our cases of polycythemia vera was much higher, ranging from $\mathbf{9 . 2}$ to 175.2 , an average of 61.2 per cent above normal, without any appreciable variation from normal in plasma volume. The differentiating point seems to be that in congestive heart failure the plasma volume is greatly increased, whereas in polycythemia vera the plasma volume is essentially normal. In individual cases total blood volume may be as high in congestive heart failure as in polycythemia vera. For this reason the hematocrit becomes a useful diagnostic procedure, and at a hematocrit level of over 55 the diagnosis of polycythemia vera is justified in the absence of physical signs of congestive heart failure.

Venous pressures were within normal limits in cases of polycythemia vera and anemia. Variations therein bore no definite relationship to either changes in blood volume or clinical condition. Circulation times varied more widely than had been anticipated but in general confirmed the findings of other workers (30). The average trend bore a constant relationship to the red cell count suggesting that, in addition to other hemodynamic factors, the speed of blood flow is to a great extent determined by the viscosity of the blood (31). In cases followed during recovery the determination of circulation time added little, if anything, to the clinical evaluation of the case.

\section{SUM MARY}

A comparison of the blood volume findings of the 2 chronic blood dyscrasias herein studied reveals certain constant trends which are common to both. All chronic anemias, regardless of etiology or duration, are strikingly similar, a fact not to be inferred from the literature. In severe anemia, circulating red cell volume is greatly reduced and may fall as low as 60 per cent below normal before clinical signs of impending collapse become evident. In this stage the plasma volume is above the normal amount for the individual in a state of health and, whether this increase be considered as purposeful or not, it has the effect of maintaining the total amount of blood available for filling of the vascular bed and maintenance of an adequate relationship between vascular volume capacity and content. Coincident with the lowering of hemoglobin concentration, and hence oxygen 
capacity of a unit mass of blood due to the red cell deficit and plasma dilution, the rate of flow is increased in relation to the lowered viscosity of the blood. During recovery the significant change is the increase in circulating red cell volume, and the relation of this increase to the course of plasma volume is such that total blood volume slowly rises from the subnormal level present in the severe stages to within normal limits for the individual when recovery is complete.

It is therefore evident that at critical levels of anemia, even though dehydration may be severe, the administration of fluids, especially intravenously, may by further dilution lower the oxygen capacity of the blood to dangerous and even fatal levels. This study also emphasizes the magnitude of reduction in circulating red cell volume in severe anemia and stresses the large amount of transfused blood necessary to raise red cell volume above critical levels. The great difference in normal total blood volume and hence red cell volume in males and females, as well as those differences due to height and surface area, must be considered in determining the amount of whole blood necessary for restoration of the circulating red cell volume to normal.

The technical procedures and time required for blood volume determination by the only satisfactory and reliable methods now available are such as to preclude them for routine clinical use, although the value of the determination in a critical case is obvious. Fortunately, there is a fairly good correlation between circulating red cell volume and hematocrit level in chronic anemia or in acute cases after hydration of the blood has occurred. The hematocrit is a better criterion of the degree of red cell volume deficit than either routine red cell counts or hemoglobin determinations.

In polycythemia vera the significant change is the tremendous increase in circulating red cell volume. It is apparent that therapeutic bleeding greatly diminishes the increased red cell mass and this fact justifies the use of this therapeutic measure in this disease. Marked clinical improvement resulted in the phlebotomized cases and symptomatic improvement was maintained as long as the total blood volume was kept down by repeated bleedings.

\section{CONCLUSIONS}

1. In chronic anemias, regardless of etiology, plasma volume is above and circulating red cell and total blood volume are below normal.

2. During recovery the relationship between the increase in circulating red cell and the decrease in plasma volume is such that total blood volume slowly increases, returning to within normal limits when recovery is complete.

3. For clinical purposes the hematocrit level is a better criterion of the degree of deficit in circulating red cell volume than the red cell count or hemoglobin determination.

4. Polycythemia vera is characterized by an increased total blood volume due entirely to a great increase in circulating red cell mass. The degree of this plethora is reflected in the erythrocyte level.

We wish to express our appreciation to Miss Evelyn Berstein for valuable technical assistance.

\section{BIBLIOGRAPHY}

1. Keith, N. M., Rowntree, L. G., and Geraghty, J. T., Method for determination of plasma and blood volume. Arch. Int. Med., 1915, 16, 547.

2. Hartwich, A., and May, G., Blutmengenbestimmungen mittels der Farbstoffmethode. Technik untersuchung an normalen, polycythämien, anämien und chlorosen. Ztschr. f. d. ges. exp. Med., 1926, 51, 497.

3. Griesbach, W., Eine klinisch brauchbare Methode der Blutmengenbestimmung. Deutsche med. Wchnschr., 1921, 47, 1289.

4. Plesch, J., Untersuchungen uber die Physiologie und Pathologie der Blutmenge. Ztschr. f. klin. Med., 1922, 93, 241.

5. Keith, N. M., Total circulating volume of blood and plasma in cases of chronic anemia and leukemia. Am. J. Med. Sc., 1923, 165, 174.

6. Herzfeld, A., Uber klinische Blutmengenbestimmung. Munch. med. Wchnschr., 1922, 69, 1272.

7. Mendershausen, A., Blutmengenbestimmungen mit der Kongorotmethode. Ztschr. f. klin. Med., 1923, 97, 468.

8. Smith, J. L., Discussion on the blood in disease. Tr. Path. Soc., London, 1900, 51, 311.

9. Robertson, O. H., and Bock, A. V., Blood volume in wounded soldiers; blood volume and related blood changes after hemorrhage. J. Exper. Med., 1919, 29, 139.

10. Bock, A. V., Constancy of volume of blood plasma. Arch. Int. Med., 1921, 27, 83.

11. Bennett, T. I., Dow, J., Lander, F. P. L., and Wright, S., Severe hemorrhage from stomach and duodenum. Lancet, 1938, 2, 651. 
12. Harrop, G. A., and Heath, E. H., Pulmonary gas diffusion in polycythemia vera. J. Clin. Invest., 1927, 4, 53.

13. Brown, G. E., and Giffin, H. Z., Studies of vascular changes in cases of polycythemia vera. Am. J. Med. Sc., 1926, 171, 157.

14. Lampe, W., Blutmengenbestimmungen bei Polycythemia Vera (Vaquez). Deutsche med. Wchnschr., 1925, 51, 2025.

15. Beltz, L., and Kaufmann, E., Symptomatologie und Therapie der Polyzythemie. Klin. Wchnschr., 1924, 41, 1855.

16. Parkes Weber, F., Polycythaemia, erythrocytosis and erythraemia. Quart. J. Med., 1908, 2, 85.

17. White, W. H., Three cases of erythraemia (polycythaemia). Lancet, 1912, 1, 7.

18. Rowntree, L. G., Brown, G. E., and Roth, G. M., The Volume of the Blood and Plasma in Health and Disease. W. B. Saunders Co., Philadelphia, 1929.

19. Haden, R. L., The red cell mass in polycythemia in relation to diagnosis and treatment. Am. J. Med. Sc., 1938, 196, 493.

20. Gibson, J. G., 2d, Clinical studies of the blood volume. VI. Changes in blood volume in pernicious anemia in relation to the hematopoietic response to intramuscular liver therapy. J. Clin. Invest., 1939, 18, 401.

21. Harris, A. W., and Gibson, J. G., 2d, Clinical studies of blood volume. VII. Changes in blood volume in Bright's disease with or without edema, renal insufficiency or congestive heart failure, and in hypertension. J. Clin. Invest., 1939, 18, 527.

22. Gibson, J. G., 2d, and Evans, W. A., Jr., Clinical studies of blood volume. I. Clinical application of method employing azo dye "Evans Blue" and the spectrophotometer. J. Clin. Invest., 1937, 16, 301.
23. Evans, Wm., Venous pressure. New England J. Med., 1932, 207, 934.

24. Winternitz, M., Deutsch, J., and Brüll, Z., Eine klinisch brauchbare Bestimmungsmethode der Blutumlaufszeit mittels Decholininjektion. Med. Klin., 1931, 27, 986.

25. Osgood, E. E., Haskins, H. B., and Trotman, F. E., Simplification of Osgood-Haskins hemoglobin method. J. Lab. and Clin. Med., 1931, 16, 482.

26. Gibson, J. G., 2d, and Evans, W. A., Jr., Clinical studies of blood volume. II. The relation of plasma and total blood volume to venous pressure, blood velocity rate, physical measurements, age and sex in ninety normal humans. J. Clin. Invest., 1937, 16, 317.

27. Murphy, W. P., and Howard, I. M., The iron content of crystals of hemoglobin prepared from human blood. (In preparation.)

28. Gregersen, M. I., Gibson, J. G., 2d, and Stead, E. A., Plasma volume determination with dyes; errors in colorimetry; use of the blue dye T-1824. Am. J. Physiol. (Proc.), 1935, 113, 54.

29. Gibson, J. G., 2d, and Evans, W. A., Jr., Clinical studies of blood volume. III. Changes in blood volume, venous pressure and blood velocity rate in chronic congestive heart failure. J. Clin. Invest., 1937, 16, 851.

30. Blumgart, H. L., Gargill, S. L., and Gilligan, D. R., Studies on velocity of blood flow. XV. Velocity of blood flow and other aspects of circulation in patients with "primary" and secondary anemia and in 2 patients with polycythemia vera. J. Clin. Invest., 1930, 9, 679.

31. Cohen, M. E., and Thompson, K. J., Studies on circulation in pregnancy. I. Velocity of blood flow and related aspects of circulation in normal pregnant women. J. Clin. Invest., 1936, 15, 607. 